\title{
Post quantum Ostrowski-type inequalities for coordinated convex functions
}

\author{
Fongchan Wannalookkhee ${ }^{1}$, Kamsing Nonlaopon ${ }^{1}$, S.K. Ntouyas ${ }^{2}$, and Huseyin Budak ${ }^{3}$ \\ ${ }^{1}$ Khon Kaen University Faculty of Science \\ ${ }^{2}$ University of Ioannina \\ ${ }^{3}$ Duzce University
}

October 4, 2021

\begin{abstract}
In this article, we give a new notion of $(\mathrm{p}, \mathrm{q})$-derivatives for continuous functions on coordinates. We also derive post quantum Ostrowski-type inequalities for coordinated convex functions. Our significant results are considered as the generalizations of other results that appeared in the literature.
\end{abstract}

\section{Hosted file}

Ostrowski.pdf available at https://authorea.com/users/439267/articles/540269-post-quantumostrowski-type-inequalities-for-coordinated-convex-functions

\section{Hosted file}

Ostrowski.tex available at https://authorea.com/users/439267/articles/540269-post-quantumostrowski-type-inequalities-for-coordinated-convex-functions 